\title{
Gender aspect of political repression (on the example of East Kazakhstan)
}

\section{DOI: 10.31551/2410-2725-2018-4-4-545-557}

\section{Zhanbosynova Albina Sovetovna}

professor of Department of history of Kazakhstan, Of he East Kazakhstan state University S. Amanzholova.

\section{Kazbekova Ainur Tatimbekovna}

senior lecturer, master of history of the Department of history of Kazakhstan Of he East Kazakhstan state University S. Amanzholova

\section{Niyazkankyzy Gul'zhanat}

k.i.n., SNS, Vostochno-Kazahstanskij gosudarstvennyj universitet im. S. Amanzholova

Annotation. Gender history and gender studies are the focus of research that is of particular interest to both men and women today. The purpose of the article is to examine the history of political repression, using gender methodology to see the position of men and women in the new status of the repressed, the transformation of their life strategies as a socio-cultural phenomenon.

The historiographical review shows that the subject of gender studies covers personal, political history, showing the intersection of male and female destinies in global historical processes. The publication analysis shows that gender studies in the post-Soviet space are at the stage of formation, including in Kazakhstan, despite the fact that it was here that the well-known Akmola camp of wives of traitors to the Motherland was located.

The basis of the study of repressive everyday life was an interdisciplinary approach. When writing the study was used synthesis of macro - and micro-historical approaches, as macrohistorical approach reflected the changing socio-economic, spiritual development, and micro-historical approach allowed us to trace the influence of macroevents on the choice of strategy of survival of the repressed.

The gender aspect of political repression has not yet become the subject of a special study, according to the documents, the families of traitors were subjected to repression in a simplified format, no investigation, no court session was held. Some of them were relatives, others their spouses and children. Probably, judging by the content of letters to the chsir, methods of derogatory violence were used, to the male half of the methods of physical violence, which is confirmed by the materials of investigative cases.

Key words: gender history; Akmola camp of wives of traitors of the Motherland; East Kazakhstan; political repressions; deportation; letters; oral history.

\section{Саяси қуғын-сүргіннің гендерлік аспектісі (Шығыс Қазақстанның мысалында)}

\section{Жанбосинова Альбина Советқызы}

тарих ғылымдарының докторы, Қазақстан тарихы қафедрасының профессоры, С. Аманжолов атындағы Шығыс Қазақстан Мемлекеттік университеті.

\section{Казбекова Айнур Татимбеққызы}

Аға оқытушы, тарих магистрі, Қазақстан тарихы қафедрасы, С. Аманжолов атындағы Шығыс Қазақстан Мемлекеттік университеті.

\section{Ниязханқызы Гүлжанат}

т.ғ.к., АҒҚ, С. Аманжолов атындағы Шығыс Қазақстан мемлекеттік университеті

Аңдатпа. Бүгінгі күні еркектер мен әйелдердің негізінде зерттеуге бағытталған гендерлік тарих пен гендерлік зерттеулер ерекше қызығушылық тудырады. Мақаланың мақсаты қуғын - сүргінге ұшыраған жаңа статустағы еркек пен әйелдің жағдайын, олардың өмірлік стратегиясының әлеуметтік - мәдени феномен ретінде өзгеріске ұшырауын гендерлік әдіснаманы қолдана отырып, саяси қуғын - сүргіннің тарихын қарастыру болып табылады.

Тарихнамалық шолу гендерлік зерттеу тақырыбы жаһандық тарихи үрдістегі еркектер пен әйелдердің тағдырларының ұштасуын көрсетіп, жеке тұлғалық, саяси тарихты қамтитындығын дәлелдеп отыр. Жарияланған мақалалар мен еңбектерді талдау барысында посткеңестік кеңістікте, соның ішінде бәрімізге белгілі отанын сатқандардың әйелдеріне арналған Акмола 
лагері орналасқан Қазақстанда да осы тақырыптағы гендерлік зерттеу қалыптасу кезеңінде екендігін көрсетіп отыр.

Қуғын - сүргіннің күнделіктіліктің зерттеу негізі пәнаралық тәсіл болып табылады. Зерттеу барысында макро және микротарихилық тәсілдердің жиынтығы қолданылды. Себебі, макротарихилық тәсіл қоғамның әлеуметтік - экономикалық, рухани дамуының өзгерістерін көрсетсе, микротарихилық тәсіл қуғын - сүргінге ұшырағандардың өз стратегиясын таңдауда көлемді оқиғалардың тигізген ықпалын анықтауға мүмкіндік береді.

Саяси қуғын - сүргіннің гендерлік аспектісі арнайы зерттеудің пәні ретінде әлі де болса қарастырылмаған. Құжаттарға назар аударатын болсақ, отанын сатқандардың отбасылары тергеусіз, сотпен қарастырылмай, жазаланды. Олардың арасында туысқандары, жұбайлары және балалары болды. ЧСИР-ге жіберілген хаттардың мазмұнына қарайтын болсақ, ер адамдарға абыройына нұқсан келтіретін күштеу тәсілдері қолданылған. Олар тергеу істерінің материалдарымен дәлелденген.

Түйінді сөздер: гендерлік тарих; АЛЖИР; Шығыс Қазақстан; саяси қуғын - сүргін; депортация; хаттар; ауызша тарих.

\section{Гендерный аспект политических репрессий (на примере Восточного Казахстана)}

\section{Жанбосинова Альбина Советовна}

доктор исторических наук, профессор кафедры истории Казахстана Восточно-Казахстанского государственного университета имени С. Аманжолова. Республика Казахстан,070004,ул. Казахстан, 55. E-mail: sovetuk@rambler.ru.

\section{Казбекова Айнур Татимбековна}

магистр истории старший преподаватель кафедры истории Казахстана Восточно-Казахстанского государственного университета имени С. Аманжолова. Республика Казахстан,070004, ул. Казахстан, 55.E-mail:akasbekova2008@mail.ru.

\section{Ниязханқызы Гүлжанат}

к.и.н., СНС, Восточно-Казахстанский государственный университет им. С. Аманжолова

Аннотация. Гендерная история и гендерные исследования в фоокусе изучения, которой находятся как мужчины, так и женщины сегодня представляют особый интерес. Цель статьи проанализировать историю политических репрессий, применяя гендерную методологию, чтобы рассмотреть положение мужчины и женщины в новом для них статусе репрессированных, трансформацию их жизненных стратегий как социокультурный френомен.

Историографический обзор свидетельствует, что тематика гендерных исследований охватывает персональную, политическую историю, показывая пересечение мужских и женских судеб в глобальных исторических процессах. Публикационный анализ свидетельствует, что гендерные исследования в постсоветском пространстве находятся на стадии становления, в том числе и в Казахстане, несмотря на то, что именно здесь располагался всем известный Акмолинский лагерь жен изменников родины.

Основой исследования репрессивной повседневности стал междисциплинарный подход. При написании исследования был использован синтез макро- и микроисторических подходов, поскольку макроисторический подход отразил изменения социально-экономического, духовного развития общества, а микроисторический подход позволил проследить влияние макрособытий на выбор стратегии выживания репрессированных.

Гендерный аспект политических репрессий еще не стал предметом специального исследования, судя по документам, семьи изменников родины подвергались репрессированию в упрощенном формате, не следствия, ни, судебного заседания не проводилось. Одни из них оказались родственниками, другие их супругами и детьми. Вероятно, судя по содержанию писем к ЧСИР применялись методы уничижительного насилия, к мужской половине методы фризического насилия, что подтверждается материалами следственных дел.

Ключевые слова: гендерная история; АЛЖИР; Восточный Казахстан; политические репрессии; депортация; письма; устная история. 


\section{УДК/ ӘОЖ 94.(574.42)}

\section{Гендерный аспект политических репрессий (на примере Восточного Казахстана) ${ }^{1}$}

\section{А.С. Жанбосинова, А.Т. Казбекова, Г. Ниязханқызы.}

Введение. Рубеж XX-XXI веков обусловил новые исследовательские направления современной исторической науки, в основе которых используется междисциплинарный подход. «Стратегия присвоения» расширила пространственные ориентиры, что позволило углубить научную проблематику исторических исследований, как по вертикали, так и по горизонтали. Научная интеграция социогуманитарных наук на текущем этапе, позволяет создать целостную картину исторического прошлого.

Составной частью современных гуманитарных междисциплинарных исследований является гендерная история, социальные конструкты которой позволяют изменить фокус научного познания. Системные конструкты гендерного подхода включают такие категории, как социальная регуляция поведения и половое взаимодействие как стратегия выживания в условиях психоэмоционального, физического насилия репрессивной политикой.

Особый интерес сегодня представляет гендерная история и гендерные исследования, в фрокусе которой находятся как мужчины, так и женщины. История политических репрессий в гендерном измерении может расширить пространственные и глубинные горизонты проблемы, имеющей актуальное значение. Фокус гендерных исследований мы направляем на историю политических репрессий, чтобы рассмотреть положение мужчины и женщины в новом для них статусе репрессированных, трансформацию их жизненных стратегий как социокультурный феномен. Основа гендерных исследований гендерное измерение, различия в поведенческой модели.

Вопросы истории политических репрессий, депортации, имеющие региональный аспект, детерминируют необходимость комплексного междисциплинарного подхода. В условиях реализации государственной программы «Рухани жанғыру» актуализируется проблематика исторических исследований краеведческого направления.

Познание собственной истории государства, стремление заполнить пустующие лакуны локальной истории, переосмысление не только ее позитивных страниц, но и беспристрастная оценка трагических страниц усиливает актуальность предложенной темы.

Обсуждение. В 1949 году вышла книга Симоны де Бовуар «Второй пол» (Бовуар, 2017), ставшей основой феминистского движения, вместе с тем отсчет гендерных исследований начинается с 80-х годов прошлого столетия. Научное пространство периодически радует ученых различными научными публикациями и учебно-хрестоматийными пособиями посвященных гендерной истории. В основном это российские историки, такие Л. Репина (Репина, 2002.), Н. Пушкарева (Пушкарева, 2001) и другие. Тематика гендерных исследований охватывает персональную, политическую историю и прочие направления. Публикационный анализ свидетельствует, что гендерные исследования в постсоветском пространстве находятся на стадии становления, в том числе и в

${ }^{1}$ Статья выполнена в рамках проекта КН МОН РК: «Память о жертвах политических репрессий (1920-1950-е гг.) и ее фиксация в сакральном ландшафте Казахстана (на примере Восточного Казахстана)» ИРН проекта AP05130870 
Казахстане. На территории Казахстана располагался всем известный Акмолинский лагерь жен изменников родины, устные истории женщин прошедших указанный лагерь периодически выставляются на сайтах интернет пространства. Исторические сюжеты рассказов, как паутина связали всю территорию СССР женскими судьбами Большого террора.

Антропологический подход, используемый Э.Б. Гучиновой в исследовании депортационной травмы калмыцкого народа, акцентирующей внимание на женской проблематике, обуславливает интерес к ее публикациям (Гучинова, 2005).

Системное изучение гендерной проблематики политических репрессий не получило пока должного освещения в исторической науке Казахстана.

Материалы и методы. Применимо к нашей проблематике показателем социальной стигмы стал репрессированный статус, что естественно обуславливает применение концепта вариативности поведения мужчин и женщин как социокультурного или социального впервые был предложенного Маргарет Мид. (Мид, 2004)

Методологическое наследие К.Леви-Стросса (Леви-Стросс, 2011), М.Фуко (Фуко, 1977) позволило рассмотреть персональную историю политических репрессий, личность, человека как социальную конструкцию в условиях политического террора, определяемого невидимыми структурами. Система микро-нарративов по Ж. Лиотару (Лиотар, 1999) определяла повседневность репрессированных, как например, мифы, озвученные в фрормате слухов среди депортированных чеченцев «о скором возвращении» на Северный Кавказ возвращала их в безоблачное прошлое.

Междисциплинарный подход в изучении репрессивной повседневности является основным, как для решения научно-исследовательских и прикладных задач, так и для понимания сущности комплексных научных методов данного исследования. При написании исследования использован синтез макро- и микроисторических подходов, поскольку макроисторический подход отражает изменения социально-экономического, духовного развития общества, а микроисторический подход позволяет проследить влияние макрособытий на выбор стратегии выживания репрессированных.

Гендерная история политических репрессированных рассматривалась в ракурсе предложенной концепции А. Людтке (Людтке, 1999), где особое внимание направлено на изучение микроистории отдельных рядовых людей или их групп, носителей повседневных интересов, а также проблем культуры как способа понимания и обобщения повседневной жизни и поведения в ней.

Авторы рассматривают адаптационные и интеграционные практики депортированных чеченцев в условиях спецпоселения в фокусе теории фронтира, опираясь на зоны взаимодействия и взаимовлияния по Т. Баррету (Барретт, 2000), акцентируя внимание на социальную, гендерную и этническую историю.

Результаты. Гендерный подход истории политических репрессий расширил источниковую базу проблемы, позволив увидеть трансформацию сознания, поведения мужчин и женщин, их социализацию в условиях режимной повседневности, осмыслить приобретенный опыт. В водовороте политических репрессий 20-50-х годов XX века оказались как мужчины, так и женщины, хотя мужское население страны они задели в большей степени. Последнее объясняется промышленными потребностями экономической модернизации СССР, в большинстве своем требовалась мужская рабочая сила для тяжелых фризических работ. 
Гендерный вопрос политических репрессий можно рассмотреть в фокусе действия приказа НКВД СССР за № 00486 и депортации народов в Казахстан.

15 августа 1937 года был издан Оперативный приказ НКВД СССР за номером 00486 (Оперативный приказ), направленный против жен изменников родины, членов право-троцкистских шпионско-диверсионных организаций, осужденных военной коллегией и военными трибуналами по первой и второй категории, начиная с 1-го августа 1936 года.

Приказ определил категории женщин, подлежащих аресту:

аресту подлежали жены, состоявшие в юридическом или фрактическом браке с осужденным в момент его ареста;

- аресту подлежали также и жены, хотя и состоявшие с осужденным, к моменту его ареста, в разводе, но:

а) причастные к контрреволюционной деятельности осужденного;

б) укрывавшие осужденного;

в) знавшие о контрреволюционной деятельности осужденного, но не сообщившие об этом соответствующим органам власти.

Согласно приказу, органы НКВД не арестовывали:

- беременных, жен осужденных, имеющих грудных детей, тяжело или заразно больные; имеющие больных детей, нуждающихся в уходе; имеющие преклонный возраст. По отношению к ним власть рекомендовала ограничиваться отобранием подписки о невыезде с установлением тщательного наблюдения за семьей.

- жен осужденных, разоблачивших своих мужей и сообщившие о них органам власти сведения, послуживших основанием к разработке и аресту мужей.

На каждую арестованную заводилось следственное дело, в которое помимо установленных документов, помещаются справки и краткое обвинительное заключение. В деле обязательно находилась подробная общая справка на семью с указанием: фамилии, имени и отчества осужденного главы семьи, за какие преступления, когда, кем и какому наказанию подвергнут; именной список состава семьи (включая и всех лиц, состоявших на иждивении осужденного и вместе с ним проживавших), подробных установочных данных на каждого члена семьи; компрометирующих материалов на жену осужденного; характеристики, в отношении степени социальной опасности детей старше 15ти летнего возраста; данных о наличии в семье престарелых и нуждающихся в уходе родителей, наличии тяжело или заразно больных, наличии детей, по своему фризическому состоянию, требующих ухода. Также заводилась отдельная краткая справка на социально-опасных и способных к антисоветским действиям детей старше 15-ти летнего возраста, именные списки детей до 15 лет отдельно дошкольного и школьного возраста. Санкцию на арест и обыск жен изменников родины, мероприятия в отношении детей арестованной и родителей, рассматривались начальниками управлений НКВД краев и областей. Во время ареста производился тщательный обыск и все имущество конфисковалось.

Члены семьи осужденного - изменника родины, попадали под действие директивы НКВД и Прокуратуры СССР №252 от 27 июля 1942 года. Дела членов семьи изменников родины рассматривало Особое совещание. По приказу №00486 репрессировались две категории, к первой относились жены руководителей, политических репрессированных; ко второй, семьи, изменников родины периода Великой Отечественной войны, перешедших на сторону врага. 
В 1937 году был арестован председатель Восточно-Казахстанского облисполкома Юсупов Шакир Якупович. Согласно содержанию протокола Шакир Юсупович был обвинен в том, что входил в состав антисоветской, националистической, террористическо-повстанческой, шпионско-диверсионной организации, и выступал руководителем в проведении шпионской, диверсионно-вредительской деятельности в Восточно-Казахстанской области. Его супруга Чулпан Шаяхметовна, проживая с ним и «зная о его антисоветской деятельности, укрывала таковую»².

Задача НКВД в период Большого террора состояла не в отдельном аресте одного человека, а в создании многоходовой операции по обезвреживанию масштабной антисоветской контрреволюционной шпионско-террористической организации, связанной с центром республики и даже Москвой. Паутина репрессивной политики связала города и людей одной статьей УК СССР 58, пункты статьи зависели от фантазии следователя. В историографии операции 1937-1938 годов именуются кулацкими, национальными: немецкими, польскими, латышскими и пр. Руководителями и членами антисоветских организаций были в основном мужчины, как например, в следственном деле Шакера Юсупова мелькали фомилии К.Сарымулдаев, У.Кулумбетова, Т.Рыскулова, А.Кальменева, У. Исаева и др. Расстрельный список Сталина расширял географию политических репрессий, втягивая новые персоналии, новые районы и области.

В 1936 году Ш.Юсупов был назначен на должность председателя Восточно-Казахстанского облисполкома. На вопрос следователя: «Дайте показания о вашей антисоветской деятельности по Восточно-Казахстанской области?» Ш. Юсупов рассказал, что ему было дано задание о подготовке повстанческих кадров, о развертывании подрывной контрреволюционной деятельности, направленной на дискредитацию хозяйственно-политических мероприятий правительства и прочая вредительская работа ${ }^{3}$.

В состав областной антисоветской организации входило местные руководители, такие как Ахатай Арынов, зав. Восточно-Казахстанского облконторы связи, Ханык Исенгилдьдин, зав. Восточно-Казахстанского облвнуторга и др.

В следственном деле Ш. Юсуповой, как члена семьи изменника родины (ЧСИР) и подобных делах ЧСИР, хранится справка, где указывался именной список состава членов семьи с подробными на них установочными данными. Состав семьи Юсуповых состоял из сына Булата шести лет, дочери Клары трех лет, племянник Юсупов Мазеп шестнадцати лет. В постановляющей части супругу Шакера Юсупова, Чулпан Юсупову изобличали в том, что она является соучастницей в антисоветской деятельности своего мужа, скрыла данный фракт от органов НКВД. 25 фревраля 1938 года Юсупов Шакер был расстрелян, как враг народа, Чулпан Юсупова была арестована 14 апреля 1938 года, на основании приказа №00486, отправили ее дело на рассмотрение Особого совещания.

По освобождении Чулпан Юсупова написала письмо Генеральному прокурору СССР тов. Руденко.

«В 1938 году я была арестована органами НКВД в г. Алма-Ате по постановлению Особого совещания при НКВД СССР была осуждена, как член семьи изменника родины. Мой муж Юсупов был арестован в 1937 году.

Срок наказания 8 лет я отбыла полностью в исправительно-трудовых лагерях в поселке №26 Карагандинских лагерей. Освобождена в 1946 году. 
У меня было двое детей, сын Болат 1931 года рождения, и дочь Клара 1934 года рождения. После моего ареста дети были оставлены на воспитание Жумашеву Абдулле, проживающему в городе Алма-Ата. Будучи в лагере, я получила известие о том, что дочь моя умерла в 1944 году, а сын был отдан в детдом. Где она находится в настоящее время, я не знаю.

После своего освобождения я разыскивала сына неоднократно, но мои розыски оказались безрезультатными и я до сих пор не знаю ничего о нем.

До ареста я нигде не работала, малограмотная, я занималась домашним хозяйством и воспитанием детей.

В настоящее время работаю в швейной мастерской мастерицей. Живу в Акмолинске с 1946 года. Прошу снять с меня судимость» ${ }^{4}$.

Нередким явлением тех лет, были межнациональные браки, как например семья Нуршанова Юсуф-Али, работавшего начальником нархозучета Восточно-Казахстанской области и Клавдии Захаровны, работавшей, начальником отдела учета и отчетности ВК Облзу.

Юсуфа-Али Нуршанова обвиняли по общепринятому в НКВД шаблону участии в антисоветской, националистической, террористическо-повстанческой, шпионско-диверсионной организации. Их организация, согласно обвинительной части «проводила диверсионную работу, подготовляла воруженное восстание, приурочивая его к моменту вторжения иностранной военной интервенции в СССР, намечала террористические акты против руководителей ВКП(б) и Советского правительства» ${ }^{5}$.В марте 1938 года Ю-А. Нуршанов был расстрелян. Из письма матери Клавдии Захаровны на имя Жданова с просьбой пересмотреть дело ее дочери, можно узнать некоторые подробности о судьбе супруги Ю-А. Нуршанова. В сентябре 1937 года Клавдию привезли из командировки по колхозам области больную, вызванный врач констатировал фриброму, требовавшей оперативного лечения. Во время нахождения Клавдии в больнице, где она получала облучение, был арестован ее муж, ее лишили партбилета. В феврале 1938 года она написала письмо на имя Сталина с просьбой восстановить в партии и разобраться с ее делом ${ }^{6}$. Следует отметить, что не освободить или разобраться с делом арестованного Ю-А. Нуршанова. 17 марта 1937 года после расстрела Ю-А. Нуршанова, арестовали Клавдию Нуршанову, Особым совещанием приговорили к 8 годам, направили в печально известный Акмолинский лагерь жен изменников родины ${ }^{7}$.

С просьбой о помиловании к Наркому, обратилась Руткунас Анна Константиновна, ее муж Петр Степанович был обвинен в шпионаже в пользу Японии по приказу 00485 (национальные операции).

«У меня забрали мужа в 1937 году 4 сентября, в чем его обвиняют, я конечно не знаю. Работал он на железной дороге 30 лет Туркестан (Турксиб примечание автора) станция Семипалатинск. После него забрали и меня в 1937 году 28 октября. На четвертый день взяли меня на допрос. На допросе следователь очень грубо со мной обращался, кричал на меня, материл меня и всякими словами и называл проституткой и б.., говорил мне, чтобы проверилась на ..., сознавайся в преступлении б.... В чем я виновата, я ничего не знаю, а он стучал кулаком по столу и кричал все грязные слова, угрожал мне всяко.

Просидела я 9 месяцев, истощала и все время болею.

\footnotetext{
${ }^{4}$ Архив ДВД ВКО Ф.19. О.2. Д. 1345. л.25

${ }^{5}$ Архив ДВД ВКО Ф.19. О.2. Д. 1518. л.12-15

${ }^{6}$ Архив ДВД ВКО Ф.19. О.2. Д. 1518. л.21

${ }^{7}$ Архив ДВД ВКО Ф.19. О.2. Д. 1518. л.21
} 
Болею туберкулезом легких, почки, сердце, грыжа, геморрой, зубов нет, болею желудком и ничего мне больше не говорили, а по окончании 9 месяцев меня отправили в Темир Актюбинской области Казахстана.

Когда меня отправляли, я спросила у начальника: «За что меня отправляет?» Он сказал: «За мужа». Я спросила: «Насколько?». Начальник ответил: «Не знаю. Приедете, там вам скажут на месте».

Когда я приехала в город Темир и спросила начальника, он мне ответил: «На вас нет никаких дел, и я ничего не знаю. Может быть и завтра вас выпустят». И проживаю 11 месяцев в ссылке в городе Темир. Нахожусь в очень тяжелом положении. Работать я не в силах, потому что больная и помощи нет ни откуда.

Прошу вашего помилования вернуть меня к своим детям, не откажите мне в вашем помиловании.

Я уже нахожусь в городе Темир в ссылке уже 11 месяцев, и не знаю своего срока и до каких пор я буду в таких тяжелых условиях. Я очень больна, и заработать себе на пропитание не могу, я уже не молодая мне уже 52 года и при том же я за мужа ничего не знаю, если он виноват, то пускай сам и отвечает. Я за него не хочу отвечать

Дорогой Нарком, прошу вас вашего помилования не отказать и вернуть меня такую больную к своим детям.

И еще, прошу вас, дайте мне срок, а то я хожу к начальнику каждый день и спрашиваю: «Какой меня срок?». А он мне говорит: «Ничего не знаю, когда придут дела, тогда скажу». Или прошу вашего помилования вернуть меня к своим детям ${ }^{8}$.

Возраст женщин не имел особого значения для репрессивной политики, многие из них оказывались в той ситуации, когда они не могли обходиться без помощи своих близких. «В ноябре месяце 1937 года 5-го дня, я была арестована органами Транспортного НКВД ж.д. Турксиба станция Чарская, где я проживала в указанное выше время. До июня месяца 1938 года, я содержалась под стражей в Семипалатинской тюрьме и в средних числах июня месяца 1938 года из под стражи была освобождена и выслана на вольногражданское проживание в Павлодарскую область г. Павлодар, без права выезда из пределов города, где я проживаю в настоящее время. С момента моего ареста т.е. с 5 ноября 1937 года и до настоящего времени мне ни каких конкретных обвинений не предъявлялось и до сих пор я не знаю за что отбываю и продолжаю отбывать не заслуженное мною наказание.

Настоящим убедительно прошу обратить ваше внимание на следующее:

Я, Спирина Екатерина Петровна, рождения 1878 года, имею уже преклонный возраст 61 год, происхождение из крестьян-бедняков, совершенно неграмотная до настоящего времени, к фризическому труду не пригодная благодаря преклонным годам. В настоящее время живу у дочери и нахожусь на иждивении.

В скором будущем дочь по служебным и семейным обстоятельствам меняет свое местожительство, т.е. выезжают из пределов Павлодарской области и я тогда должна остаться в Павлодаре одна. Я, которая имеет преклонный возраст - 61 год, неграмотная, нетрудоспособная, недоумеваю, как и на что я буду продолжать свое существование.

Кроме всего вышеизложенного, положенное на меня пятно неизвестного для меня обвинения в корне не соответствует своему назначению и я за собой

${ }^{8}$ Архив ДВД ВКО Ф.19. О.2. Д. 1957. л.18-19 
никогда не чувствовала и не чувствую ни какой ноты преступного деятельности и мне на старости лет приходится отбывать не заслуженное мной наказание.

Настоящим еще раз убедительно прошу вас обратить ваше внимание на вышеизложенное, в порядке надзора пересмотреть мое дело и вынести ваше заключение, как для человека, который отживает последние дни своего существования и которому необходимо сейчас только старческий покой, который может представить моя родная дочь.

Поэтому еще раз прошу вас ускорить в пересмотре моего дела и разрешить мне право выезда из пределов Павлодарской области и выдаче мне паспорта» ${ }^{9}$.

Вышеуказанные «письма во власть», как источники личного происхождения стали новым исследовательским направлением исторической науки. Письма, оказавшиеся в делах репрессированных, отражают эмоциональный фон и паническое состояние. Стиль письма демонстрирует идеологическое клише обращение вышестоящие органы как попытка наладить коммуникативные связи с центральным аппаратом, найти правду, которая может спасти их.

Депортация оставила трагический след в исторической памяти народов. Коллективная идентичность чеченского народа восприняла депортацию как культурную травму, момент высылки являлся самым драматичным в исторической памяти. В фокусе памяти всплывают голод, смерть близких в пути следования, безразличие и жестокость конвоиров к людским жизням, вспоминая, что конвоиры готовы были выбросить ребенка (или тяжелобольного человека) из вагона, считая его мертвым.

По воспоминаниям многих переселенцев, наиболее болезненным в фризическом и нравственном плане в пути стал вопрос отправления естественных надобностей, который оказался совершенно непродуманным, эшелоны по несколько часов шли, не останавливаясь. Ширвани Базаев рассказывает: «Вагоны останавливали, когда вздумается через 3-10 часов. Когда останавливали поезд, по нужде, естественно женщины бегут в одну сторону, а солдаты стреляют, нет вместе, в одну сторону гнали. У чеченцев такого не было, был свой этикет. Многие умирали из-за разрыва мочевого пузыря. Рожали, умирали в вагонах» ${ }^{10}$. Депортация не учитывала гендерный аспект спецпереселенцев, стратегии выживания мужчин и женщин в столь дискомфортных условиях этапирования, обуславливали возникновение различных адаптационных практик.

Как отмечает исследователь депортации калмыков Э-Б.М. Гучинова, что кроме буржуйки, других удобств скотский вагон не предусматривал. Многие женщины, стесняясь мужчин, перебирались под составом на другую сторону, чтобы там оправиться. Неповоротливые старые бабки не раз погибали под колесами двинувшегося состава. (Гучинова, 2005: 77) Сопоставляя бытовые условия в пути калмыков и чеченцев, она отмечает, что когда в таких же вагонах выселяли чеченцев, они старались организовать пространство «телятника» в соответствии с привычными культурными нормами гендерной сегрегации. (Гучинова, 2005: 79)

Тяжелые бытовые условия в эшелонах подтверждаются и воспоминаниями информанта У.С. Сулейманова: «У одного мужчины оказался топор, он сделал 
в вагоне дырку. Это и были «туалеты». Я ехал с мамой, с тремя сестрами, братом. Женщины, молодые девушки, парни стеснялись» ${ }^{11}$.

Х.3. Довтабаева вспоминает: «Мой муж Магомадов Саидселимович, 1924 г.р. рассказывал, когда ехали в пути, его отец по нужде вышел, его задавило поездом. Хоронить не дали его, только смогли снегом прикрыть» ${ }^{12}$.

24 июня 1942 года вышло Постановлением ГКО-1926сс «О членах семей изменников родины», согласно которому совершеннолетние члены семей военнослужащих и гражданских за переход на сторону врага, предательство или содействие немецким оккупантам, за службу в карательных органах немецких оккупантов, подлежали аресту и ссылке в отдаленные местности СССР. Членами семьи изменника родины считались отец, мать, муж, жена, сыновья, дочери, братья и сестры, если они жили совместно с изменником родины или находились на иждивении к моменту совершения преступления. (Главные документы, 2015: 61)

Предательство нельзя оправдать, и как не вспомнить слова И. Сталина: «сын за отца не отвечает», добавив строки стихотворения А. Твардовского:

...Вас не смутить в любой анкете

Зловещей некогда графой:

Кем был до вас еще на свете

Отец ваш, мертвый иль живой...

В годы Великой Отечественной войны семьи красноармейцев, нарушивших присягу и перешедших на сторону немцев подлежали наказанию согласно Постановлению ГКО 1926сc. В обращении начальнику МВД Казахской ССР, Александра Алексеевна Мищенко писала: «...с двумя детьми была сослана в Павлодарскую область сроком на пять лет за мужа Мищенко Сергея Алексеевича, который в то время находился на фронте. Что с ним случилось, и за что я пострадала, не знаю. ...Имевшееся имущество полностью конфисковано». В октябре 1942 года Сергей Мищенко был расстрелян как изменник родины, а семья была выслана 15 мая 1943 года ${ }^{13}$.

Анализируя письма женщин, переживших тюрьмы НКВД, попавших из комфрортного пространства в зону насилия и бесправия, лишившись одномоментно семьи, мужа, детей оказались в тяжелейшей жизненной ситуации. Главная их вина заключалась в том, что они оказались замужем за мужчинами, которых обвиняли в антисоветской деятельности и в шпионаже. Зная об их контрреволюционной деятельности, они оказывались соучастницами и недонесли на своих мужей. Женщины в письмах обращались в вышестоящие организации, просили пересмотреть их дело, говоря, что ни какой вины за собой не имеют, и никто ни разу не предъявлял им обвинения. Если их муж в чем, то виновен, то они о его преступлении ничего не знают, и никогда не знали. Даже давали честное гражданское слово, а некоторые задавали вопрос, почему они должны нести большое наказание за них. «Я как малограмотная женщина не могу понять, в чем я являюсь виновной. За время моего нахождения в Семипалатинской тюрьме 9 месяцев, был один допрос, мне предъявили пункты 6-9. Когда я спросила, что означают эти пункты, мне сказали 6 - это шпионаж, а 9 так себе, шахер-махер. И вот теперь я нахожусь в ссылке уже год и 9 месяцев тюрьмы.

\footnotetext{
${ }^{11}$ Полевые исследования. Сулейманова У.С., 2014

${ }^{12}$ Полевые исследования. Довтабаева., 2016

${ }^{13}$ Архив ДВД ВКО Ф.19. О.2. Д. 3641., л.10
} 
В ссылке я нахожусь в г. Темир Актюбинской области. А когда отправляли, я спросила: за что отправляют? Сказали из-за мужа» ${ }^{14}$

Жены, арестованных мужей оправдывались, а порой ощущали чувство вины, что ничего компрометирующего о нем, о своем супруге они не знали, и ничего не замечали. В тот самый момент, когда с партийных трибун обращались к народу, когда все информационное пространство советского социума заполняли идеологемами «Враг не дремлет», жены «продремали» врага под боком. Следствием утери их «бдительности» стал новый статус «Член семьи изменника Родины» (ЧСИР).

Содержание протоколов допроса не отличалось разнообразием, стандартная фраза: «Следствие располагает данными, что вы, проживая с мужем_, знали о его контрреволюционной деятельности, скрывали ее и сами проводили антисоветскую работу. Дайте правдивые показания по этому вопросу». Менялась только фамилия супруга и супруги.

В содержании дел ЧСИР, в частности женщин не у всех есть документальное подтверждение о вынесении приговора судебного или внесудебного органа. Постановляющей части большинства дел, есть обращение к телеграфному распоряжению Зам. Наркомвнутдела СССР Комкора тов. Фриновского от 25 ноября 1937 года за №49912. Согласно данному распоряжению, арестованных женщин освобождают и высылают на местожительство в отдаленные районы одной из областей Казахстана. Указанный факт подтверждается в письмах обращениях, жалобах, аппретируемых к вышестоящему руководству.

При наличии родственников репрессированных родителей по Приказу 00486, детей отдавали им, в случае отсутствия их отправляли в детприемник, где начальники писали расписки о том, что приняли ребенка, арестованного органами НКВД для дальнейшего воспитания в детдомах Наркомпроса, как оставшегося без родителей и детдома несут полную ответственность за их воспитание.

Заключение. В категорию ЧСИР попадали жены руководителей и их дети, типичный портрет жены, административно ссыльной - статус домохозяйки, редко кто из них имел хорошее образование, большинство были малограмотные. Наивность их обращений может умилять с высоты нашего времени. Но с позиции той текущей ситуации, вера в справедливость, вера в советское правосудие, вера в ошибку превалировала, и жены писали, и неоднократно, что отмечалось в письмах. В тот самый момент, когда арестовывали женщин, мужчин уже расстреляли. В большинстве своем они все занимали руководящие посты, имели образование и были членами партии, в национальных операциях наличие должности и образование особого значения не имели.

Внезапность насильственного переселения в сочетании с психологическими испытаниями разрушили привычный мир чеченцев, как и практически всех депортированных народов. Традиционное гендерное разделение депортированных было уничтожено общим вагонным пространством, где живые и мертвые находились вместе, где старшее поколение было низвергнуто с почетного пьедестала, где было стерто пространство интимности с естественных физиологических надобностей.

Гендерный аспект политических репрессий еще не стал предметом специального исследования, судя по документам, семьи изменников родины подвергались репрессированию в упрощенном формате, не следствия, ни,

${ }^{14}$ Архив ДВД ВКО Ф.19.О.2. Д.1955., л. 18 
судебного заседания не проводилось. Одни из них оказались родственниками, другие их супругами и детьми. Вероятно, судя по содержанию писем к ЧСИР применялись методы уничижительного насилия, к мужской половине методы физического насилия, что подтверждается материалами следственных дел.

Численность репрессированных мужчин значительно больше, чем женщин, что объясняется второстепенной ролью женщины, нужно учитывать, что ЧСИР результат репрессивных процессов Большого террора и закона военного времени.

\section{Әдебиеттер тізімі/ Список литературы}

1. Бовуар С. Второй пол. М.: Азбука, 2017. 928 с.

2. Барретт Т.М. Линия неопределенности: северокавказский «фронтир» России // Американская русистика: вехи историографии последних лет. Имперский период. Самара, 2000. С. 163-195.

3. Гучинова Э.-Б.М. Из Тбилиси в Сибирь: депортация армян в дневнике Арпик Алексанян// Электронный ресурс. URL: http://levonabrahamian.com/cntnt/publicatio/articles_b/stati/eb_guchino.html; Я - высланная, ты - без ноги". (дата обращения 21.07.2018)

4. Гучинова Э.-Б.М. Депортация калмыков (1943-1956): гендерный взгляд// Электронный ресурс. URL: http://www.elzabair.ru/cntnt/lmenu/stati/deportaciy.html (дата обращения 21.07.2018)

5. Гучинова, Э.-Б. М. Помнить нельзя забыть. Антропология депортационной травмы калмыков. Штутгарт: ibidem, 2005. 282 c.

6. Главные документы Великой Отечественной войны 1941-1945. М.:Комсомольская правда, 2015. $400 \mathrm{c}$.

7. Леви-Стросс Кл. Структурная антропология. М.: «Астрель», 2011. 544 с.

8. Лиотар Ж-Ф. Состояние постмодерна. Перевод с фрранцузского Н. А. Шматко. Институт экспериментальной социологии, Москва Изд-во "АЛЕТЕЙЯ", Санкт-Петербург, 1999. 288 с.

9. Людтке А. «История повседневности» в Германии после 1989 года // Казус: индивидуальное и уникальное в истории. 1999. (вып. 2). М., 1999. С. 117-126.

10. Мид М. Мужское и женское: исследование полового вопроса в меняющемся мире. М.: Российская политическая энциклопедия (РОССПЭН), 2004. 416 с.

11. Оперативный приказ Народного Комиссара Внутренних Дел Союза СССР № 00486 от 15 августа 1937 года// Электронный ресурс. URL: https://blog.stepanivanovichkaragodin.org/?p=606 (дата обращения 14.08.2014

12. Пушкарева Н. От 'His-stori' к 'Her-stori': рождение исторической фреминологии // Адам и Ева. Альманах гендерной истории. М., 2001. № 1.

13. Репина Л.П. Женщины и мужчины в истории: Новая картина европейского прошлого. Очерки. Хрестоматия. М., 2002.

14. Фуко М. Слова и вещи. Археология гуманитарных наук. М., 1977. 488 с.

\section{References}

Bovuar, 2017 - Bovuar S 2017 Vtoroj pol. M.: Azbuka. 928 s. (in Rus).

Barrett, 2000 - Barrett, TM 2000 Liniya neopredelennosti: severokavkazskij «frontir» Rossii // Amerikanskaya rusistika: vekhi istoriografii poslednih let. Imperskij period. Samara, 2000. S. 163195. (in Rus).

Guchinova, - Guchinova, E-BM, Iz Tbilisi v Sibir': deportaciya armyan v dnevnike Arpik Aleksanyan// EHlektronnyj resurs. URL: http://levonabrahamian.com/cntnt/publicatio/articles_b/stati/eb_guchino.html; YA - vyslannaya, ty bez nogi". (data obrashcheniya 21.07.2018)

Guchinova, - Guchinova, E-BM, Deportaciya kalmykov (1943-1956): gendernyj vzglyad// EHlektronnyj resurs. URL: http://www.elzabair.ru/cntnt/Imenu/stati/deportaciy.html (data obrashcheniya 21.07.2018)

Guchinova, - Guchinova, E-BM, 2005 Pomnit' nel'zya zabyt'. Antropologiya deportacionnoj travmy kalmykov. SHtutgart: ibidem, 2005. 282 s. (in Rus).

Glavnye, 2015 - Glavnye, 2015 dokumenty Velikoj Otechestvennoj vojny 1941-1945. M.:Komsomol'skaya pravda. $400 \mathrm{~s}$. (in Rus).

Levi-Stross, 2011 - Levi-Stross, Kl 2011 Strukturnaya antropologiya. M.: «Astrel'». 544 s. (in Rus). 
Liotar, 1999 - Liotar, ZH-F 1999 Sostoyanie postmoderna. Perevod s francuzskogo N. A. SHmatko. Institut ehksperimental'noj sociologii, Moskva Izd-vo "ALETEJYA", Sankt-Peterburg. 288 s. (in Rus).

Lyudtke, 1999 - Lyudtke, A 1999 Istoriya povsednevnosti v Germanii posle 1989 goda // Kazus: individual'noe i unikal'noe v istorii. 1999. (vyp. 2). M. S. 117-126. (in Rus).

Mid, 2004 - Mid, M 2004 Muzhskoe i zhenskoe: issledovanie polovogo voprosa v menyayushchemsya mire. M.: Rossijskaya politicheskaya ehnciklopediya (ROSSPEHN). 416 s. (in Rus).

Operativnyj prikaz Narodnogo Komissara Vnutrennih Del Soyuza SSSR № 00486 ot 15 avgusta 1937 goda// EHlektronnyj resurs. URL: https://blog.stepanivanovichkaragodin.org/?p=606 (data obrashcheniya 14.08.2014(in Rus).

Polevye issledovaniya. SH. Bazaev., 2014

Polevye issledovaniya. U.S. Sulejmanova 2014

Polevye issledovaniya. Dovtabaeva, 2016

Pushkareva, 2001 - Pushkareva, N 2001 Ot 'His-stori' k 'Her-stori': rozhdenie istoricheskoj feminologii // Adam i Eva. Al'manah gendernoj istorii. M. № 1. (in Rus).

Repina, 2002 - Repina, LP 2002 ZHenshchiny i muzhchiny v istorii: Novaya kartina evropejskogo proshlogo. Ocherki. Hrestomatiya. M. (in Rus).

Fuko, 1977 - Fuko, M 1977 Slova i veshchi. Arheologiya gumanitarnyh nauk. M. 488 s. (in Rus). 